\title{
Rapid spread of a fleshy-fruited species in abandoned subalpine meadows - formation of an unusual forest belt in the eastern
}

\section{Carpathians}

Tomasz Durak ${ }^{(1)}$, Magdalena Zywiec $^{(2)}$, Pawel Kapusta ${ }^{(2)}$, Jan Holeksa ${ }^{(3)}$

\begin{abstract}
In recent decades, most subalpine hay meadows and pastures have been abandoned, and trees have been recolonizing these sites where forest existed before agricultural activity. This study examined how woody vegetation, dominated by the deciduous fleshy-fruited tree Sorbus aucuparia (rowan), expanded on subalpine meadows in the Western Bieszczady Mountains (eastern Carpathians, Poland) after the cessation of agricultural use. The aims were to determine the abundance of rowan in the woody vegetation, to estimate the rate of rowan expansion in the studied area, and to characterize the variability of rowan stands and growth forms. Rowan dominated the current plant community of abandoned subalpine meadows, though this species is not considered a rapid colonizer of open areas and was not frequent in the uppermost forest belt before the colonization. The whole area was encroached by rowans in a very short period of time 60-70 years ago. Rowan tree density was similar throughout the elevational gradient but the growth form changed, becoming more shrub-like with increasing elevation. Rowan stands will likely be the main element of the subalpine belt in this region in the upcoming decades. At present, no tree species can be considered a rapid successor to rowan in the area.
\end{abstract}

Keywords: Abandoned Subalpine Meadows, Forest Recolonization, Land Use Change, Subalpine Forest, Succession of Woody Vegetation

rest encroachment into subalpine scrubland and grassland (Gehrig-Fasel et al. 2007, Weisberg et al. 2013).

Carpathians subalpine forests cover an elevation range from about $1200-1500$ to 1250-1650 m a.s.l. (Zarzycki 1963, Sitko \& Troll 2008), and are mostly formed of Picea abies (L.) H. Karst., accompanied in some areas by other coniferous species: Larix decidua Mill., Pinus cembra L. and Pinus sylvestris $L$. The uppermost forest belt may also include deciduous tree species, mostly beech (Fagus sylvatica L.) and less frequently sycamore (Acer pseudoplatanus L.), birches (Betula pendula Roth and B. pubescens Ehrh.), or rowan (Sorbus aucuparia L.). During the expansion of subalpine fo-

(1) Department of Botany, University of Rzeszów, ul. Zelwerowicza 4, PL-35-601 Rzeszów (Poland); (2) Institute of Botany, Polish Academy of Sciences, ul. Lubicz 46, PL-31-512 Kraków (Poland); (3) Adam Mickiewicz University, Faculty of Biology, Department of Plant Ecology and Environment Protection, ul. Umultowska 89, PL-61-614 Poznan (Poland)

@ Tomasz Durak (tdurak@univ.rzeszow.pl)

Received: Oct 10, 2014 - Accepted: Jul 17, 2015

Citation: Durak T, Zywiec M, Kapusta P, Holeksa J (2015). Rapid spread of a fleshy-fruited species in abandoned subalpine meadows - formation of an unusual forest belt in the Eastern Carpathians. iForest 9: 337-343. - doi: 10.3832/ifor1470-008 [online 2015-11-20]

rest, the most dynamic changes usually occur along the timberlines composed of conifers such as P. abies (Sitko \& Troll 2008), Pinus uncinata Ram. (Camarero \& Gutiérrez 2004) or L. decidua (Didier 2001) which are anemochorous species. Over the entire Carpathian range, F. sylvatica forest is less responsive to favorable climatic changes and agriculture cessation than coniferous forests, resulting in a relatively stable timberline (Kucharzyk 2004, Weisberg et al. 2013).

Generally, tree species colonizing subalpine non-forest areas are those belonging to the uppermost forest belt (Albert et al. 2008, Holtmeier 2009, Chauchard et al. 2010), with several exceptions. Sitko \& Troll (2008) found abandoned meadows above the anthropogenic beech timberline in the Ukrainian Carpathians commonly colonized by wind-dispersed spruce. An unusual situation occurs also in the Western Bieszczady Mountains (eastern Carpathians, Poland), where the cessation of agriculture also led to the recolonization of abandoned meadows by the forest, though its species composition is different as compared with those prevailing in the uppermost forest belt. Indeed, the anthropogenic upper forest limit was previously formed by beech forests with small admixtures of A. pseudoplatanus and S. aucuparia. Such meadows were first colonized by Alnus viridis (Chaix) DC. in LAM. \& DC. 
(Schramm 1958, Zarzycki 1963). Surprisingly, after about 70 years of secondary succession, rowan was the woody species that expanded most abundantly in the subalpine belt of the Western Bieszczady Mountains (Durak et al. 2013, 2015). In particular, rowan is currently the dominant species in some areas of this region, resulting in the formation of a new forest belt above the former upper limit of beech forests (Fig. 1). In this study, we examined two aspects of rowan stand formation after colonization of abandoned subalpine meadows in the Western Bieszczady Mountains, namely: (i) how quickly rowan has spread over meadow areas; and (ii) what was the structure of stand after approximately 70 years of recolonization. The specific aims of this study were to: (1) determine the abundance of rowan in the woody vegetation that developed in abandoned subalpine meadows; (2) estimate the rate of rowan expansion; and (3) examine the variability of rowan stand and growth form characteristics in relation to habitat conditions.

\section{Methods}

\section{Study site}

The study was conducted in the subalpine area of the Western Bieszczady Mountains (eastern Carpathians, southern Poland), where the original vegetation was likely made by scattered clumps of $S$. aucuparia and $A$. viridis stretching from the natural upper timberline (1150-1260 m a.s.l. - Zarzycki 1963) to the mountain top (up to 1350 $\mathrm{m}$ a.s.l.). Starting since $15^{\text {th }}$ century, pastures and hay meadows have been created by clearcut, determining a shift downward of the natural timberline. Such deforestation activity ended in the middle of the $19^{\text {th }}$

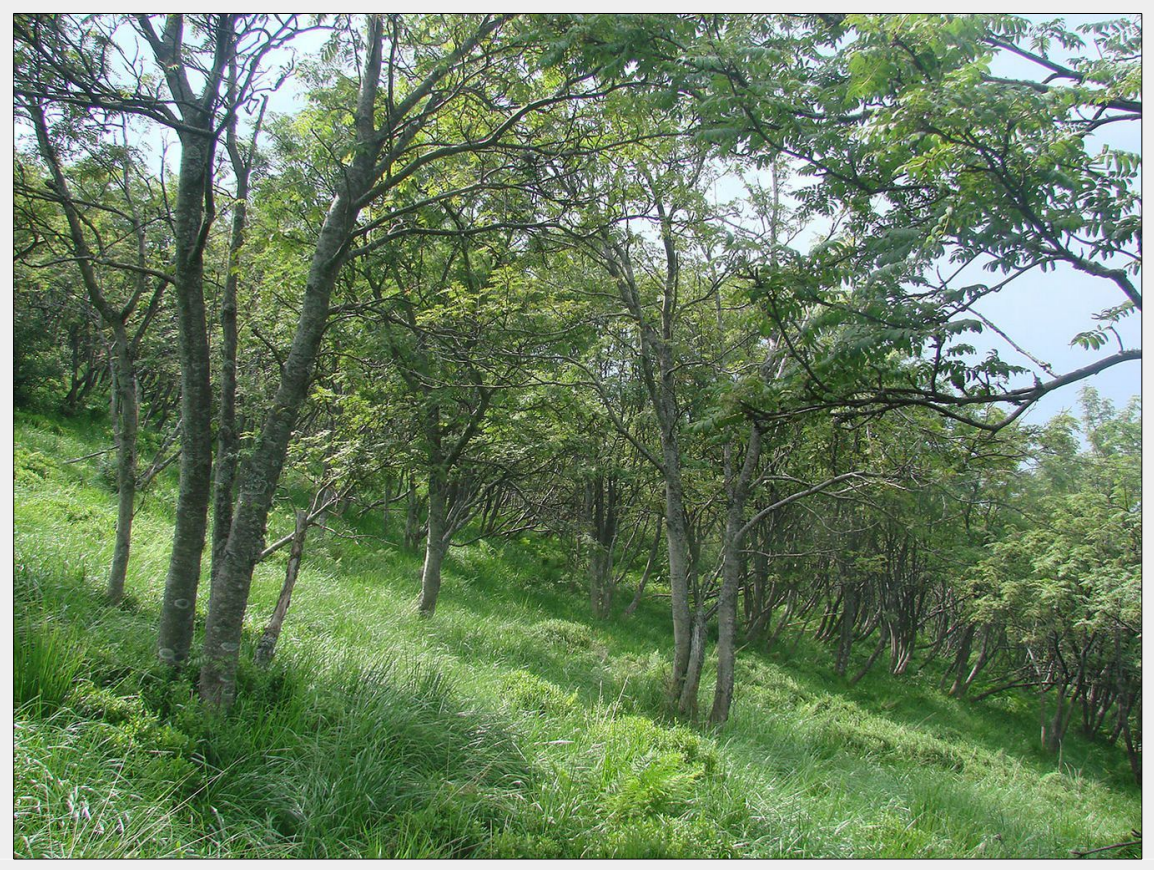

Fig. 1 - Vegetation belt dominated by rowan tree stand on the Bukowe Berdo ridge (eastern Carpathians, southern Poland). century: in the 1940s the agricultural use of subalpine meadows in the Western Bieszczady Mountains was completely abandoned, and woody vegetation began to encroach (Kucharzyk \& Augustyn 2012). In 1973, the whole area was included into the Bieszczady National Park and became part of the Eastern Carpathian International Biosphere Reserve in 1998.

The study area comprised the subalpine belt of the Bukowe Berdo ridge $\left(49^{\circ} 6^{\prime} 0^{\prime \prime}\right.$ $\mathrm{N}, 22^{\circ} 43^{\prime} 50^{\prime \prime} \mathrm{E}, 1238 \mathrm{~m}$ a.s.l.). According to archival cadastral maps, this area was used as pasture for cattle in 1852 and in later decades. Agriculture in this area was moderately intensive, and further decreased after World War I. Indeed, some scrublands are reported on the Bukowe Berdo ridge on the 1937 map, suggesting that the abandonment of subalpine meadows in this area started earlier than in other parts of the region (Kubijowicz 1926, Kucharzyk \& Augustyn 2008, 2012).

The study site encompassed approximately a 22-hectare area of a former subalpine meadow, now largely colonized by rowan stands, just above the beech timberline that represented the upper forest limit before the abandonment. The site stretched over the NE and SW slopes of the massif (mean slope: $18.5^{\circ}$; range: $5-35^{\circ}$ ), from the sheltered vicinity of the beech forest limit to the most elevated places of the mountain ridge (range 1111-1214 m a.s.l.). Soil type varied across the study site, with dystric cambisols at lower elevations and lithosols, regosols, rankers and umbric rankers at higher elevations closer to the ridge (Skiba et al. 1998). Only the area where rowan saplings were present was considered in this study. 
and minimal values corresponded to opposite facing slopes: $N(-1)$ and $S(1)$. This variable was assumed to represent the gradient of microclimatic conditions in the sampling area. A categorical variable was used for soil type, with value "o" for initial soils such as lithosols, regosols, rankers and umbric rankers, or " 1 " for more developed soils, i.e., dystric cambisols.

For each plot, tree density and total basal area (per hectare) were calculated for each woody species. For rowan, the density of all shoots (per hectare) was also determined. The relative number of individuals and relative basal area of each woody species in each plot $\left(100 \mathrm{~m}^{2}\right)$ were also calculated. Basal area was calculated using the dbh of all stems taller than $1.3 \mathrm{~m}$. The age of the oldest rowan tree sampled at a given plot was taken as the approximate time of tree establishment. We recorded the maximum height, mean stem diameter, mean number of stems per individual (at ground level) and mean number of twigs per stem (at breast height) of live rowans in each plot.

Non-normally distributed data (continuous variables) were transformed using logarithmic or exponential functions, according to Okland et al. (2001). To explain the variability of rowan tree stand and growth form characteristics, multiple regressions were performed usin the following predictors : aspect, elevation, slope and soil type. Significant predictors were identified using a forward stepwise selection procedure.

\section{Results}

\section{Tree stand characteristics}

The studied stand was mainly formed by rowan, which averaged $81.7 \%$ (range: 36.4 $100 \%$ ) of all tree individuals per plot. Other tree species were $A$. pseudoplatanus (10.4\%), F. sylvatica (3.5\%), A. viridis (3.4\%), Abies alba Mill. (0.6\%), P. abies (0.2\%) and Salix silesiaca Willd. (0.2\%). Rowan basal area averaged $18.4 \mathrm{~m}^{2}$ ha-1 (range: $3.6-34.3$ $\mathrm{m}^{2} \mathrm{ha}^{-1}$ ), accounting for $90.3 \%$ (range: $28.1-$ $100 \%$ ) of the total stand basal area. The density of rowan trees ranged from 300 to

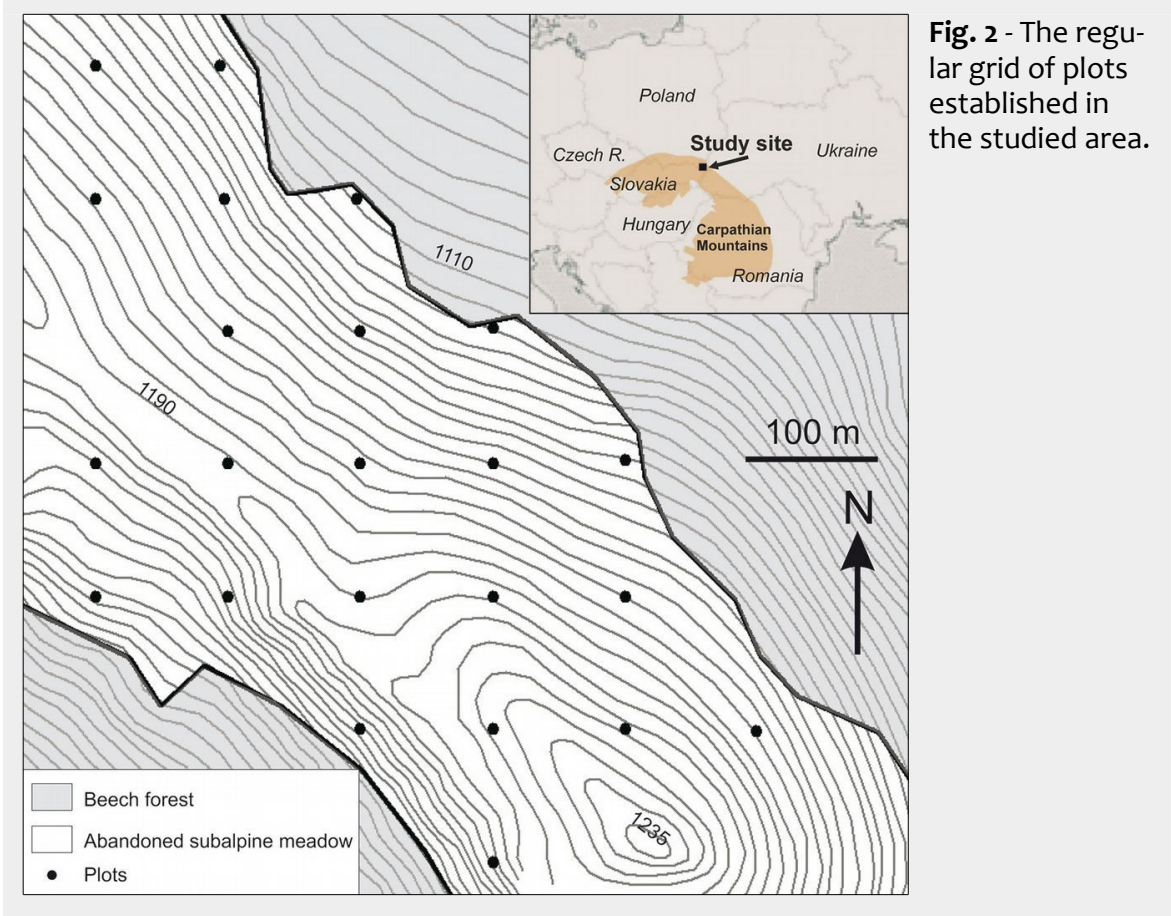

2700 individuals ha-1 (mean: 1330 ind. ha ${ }^{-1}$ ), ronmental data.

and the density of rowan shoots ranged Multiple regressions showed that almost from 500 to 27100 ha $^{-1}$ (mean: 6990 ha $^{-1}$ ). all stand characteristics were independent Stand age, as indicated by the age of the of the environmental variables (Tab. 1). oldest rowan tree, ranged from 57 to 75 Only the density of rowan shoots was sigyears (mean: 65 years). Some of the tree nificantly associated to a topographic grastand characteristics were highly corre- dient, increasing with elevation. Elevation lated (Appendix 1).

In a preliminary analysis, Pearson's correlation tests were used to explore the strength of associations between variables within the explanatory data set (environmental variables) and response data set (rowan variables - Appendix 1). This analysis showed that plot elevation was strongly correlated with the distance between plots and the edge of the beech forest $(r=0.62$; $p<0.002$ ). The nature of the relationship between these parameters and rowan variables suggested that plot elevation is a causative variable. Therefore, the distance to the edge of the beech forest was selected and excluded from further analysis to reduce multicollinearity in the envialso seemed to affect the distribution of some other species. For example, F. sylvatica was present only at lower elevations close to the upper limit of the beech forest, whereas $A$. viridis was absent from the lowest plots (Fig. 3). However, the total share of non-rowan species in the total number of tree individuals and the total stand basal area was the same regardless of elevation.

\section{Rowan growth form}

The diameter of rowan individuals averaged 7.4 (range: $1.3-16.5 \mathrm{~cm}$ ) and the maximum height of individuals averaged 9.7 (range: $4.5-17.5 \mathrm{~m}$ ). The mean basal area of rowan ranged from 36.1 to $422.9 \mathrm{~cm}^{2}$ ha $^{-1}$ (mean: $171.4 \mathrm{~cm}^{2} \mathrm{ha}^{-1}$ ). The mean number of

Tab. 1 - Effects of plot parameters on the characteristics of rowan tree stand and growth form illustrated by standardized (Beta) coefficients of multiple regression. $\left(R_{\text {adj }}^{2}\right)$ : adjusted $R^{2} ;(F)$ : the $F$ ratio; $(p)$ : significance level; $(-)$ : variable was not included in the model; $(*): p<0.05 ;(* *): p<0.01 ;(* * *): p<0.001$.

\begin{tabular}{|c|c|c|c|c|c|c|c|c|}
\hline \multirow{2}{*}{ Group } & \multirow{2}{*}{ Dependent variable } & \multicolumn{3}{|c|}{ Regression summary } & \multicolumn{4}{|c|}{ Beta coefficients } \\
\hline & & $R_{\text {adj }}^{2}$ & $\mathbf{F}$ & $p$ & Aspect & Elevation & Slope & Soil \\
\hline \multirow{7}{*}{$\begin{array}{l}\text { Iree } \\
\text { stand }\end{array}$} & Age of oldest rowan & 2.7 & 1.3 & 0.294 & - & & 0.271 & 0.228 \\
\hline & SD of age of oldest rowans & 4.0 & 1.5 & 0.255 & - & 0.213 & -0.252 & - \\
\hline & Density of live rowans (ind. per ha) & 10.2 & 3.5 & 0.075 & - & & -0.378 & - \\
\hline & Density of rowan shoots (per ha) & 33.9 & 4.8 & 0.012 & - & $0.731^{* *}$ & -0.254 & 0.435 \\
\hline & Percentage of species other than rowan & 7.6 & 1.9 & 0.176 & - & -0.552 & - & -0.338 \\
\hline & Percentage of species other than rowan in total basal area & 14.7 & 2.9 & 0.078 & -0.316 & -0.344 & - & - \\
\hline & Total basal area of rowans $\left(\mathrm{m}^{2} \mathrm{ha}^{-1}\right)$ & 3.0 & 1.7 & 0.208 & - & - & 0.273 & - \\
\hline \multirow{5}{*}{$\begin{array}{l}\text { Growth } \\
\text { form }\end{array}$} & Mean basal area of individuals & 28.9 & 9.9 & 0.005 & - & - & $0.567^{* *}$ & - \\
\hline & Maximum height of individuals $(\mathrm{m})$ & 57.1 & 10.8 & $<0.001$ & - & $-0.790^{* *}$ & 0.307 & -0.205 \\
\hline & Mean dbh of individuals $(\mathrm{cm})$ & 53.2 & 9.4 & $<0.001$ & - & $-0.850^{* * *}$ & 0.172 & -0.222 \\
\hline & Mean number shoots per individual & 17.7 & 3.4 & 0.055 & -0.276 & $0.428^{*}$ & - & - \\
\hline & Mean number of twigs per stem & 34.4 & 12.5 & 0.002 & - & $0.611^{* *}$ & - & - \\
\hline
\end{tabular}


Fig. 3 - Relationship between elevation and density of F. sylvatica, $A$ pseudoplatanus, $A$ viridis.
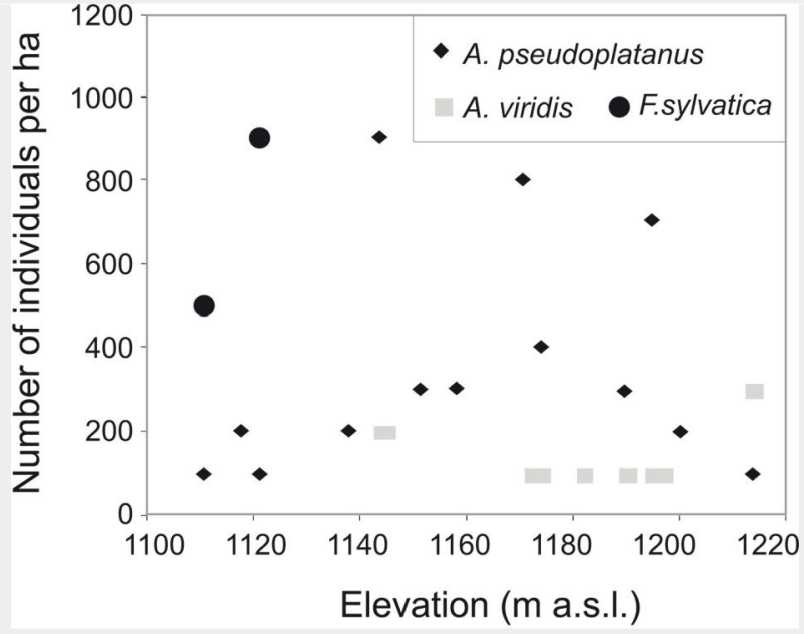

shoots per individual averaged 5.5 (range: 1-13.5) and the mean number of twigs per stem averaged 78.8 (range: 4-399). Some of the rowan growth form characteristics were highly correlated (Appendix 1).
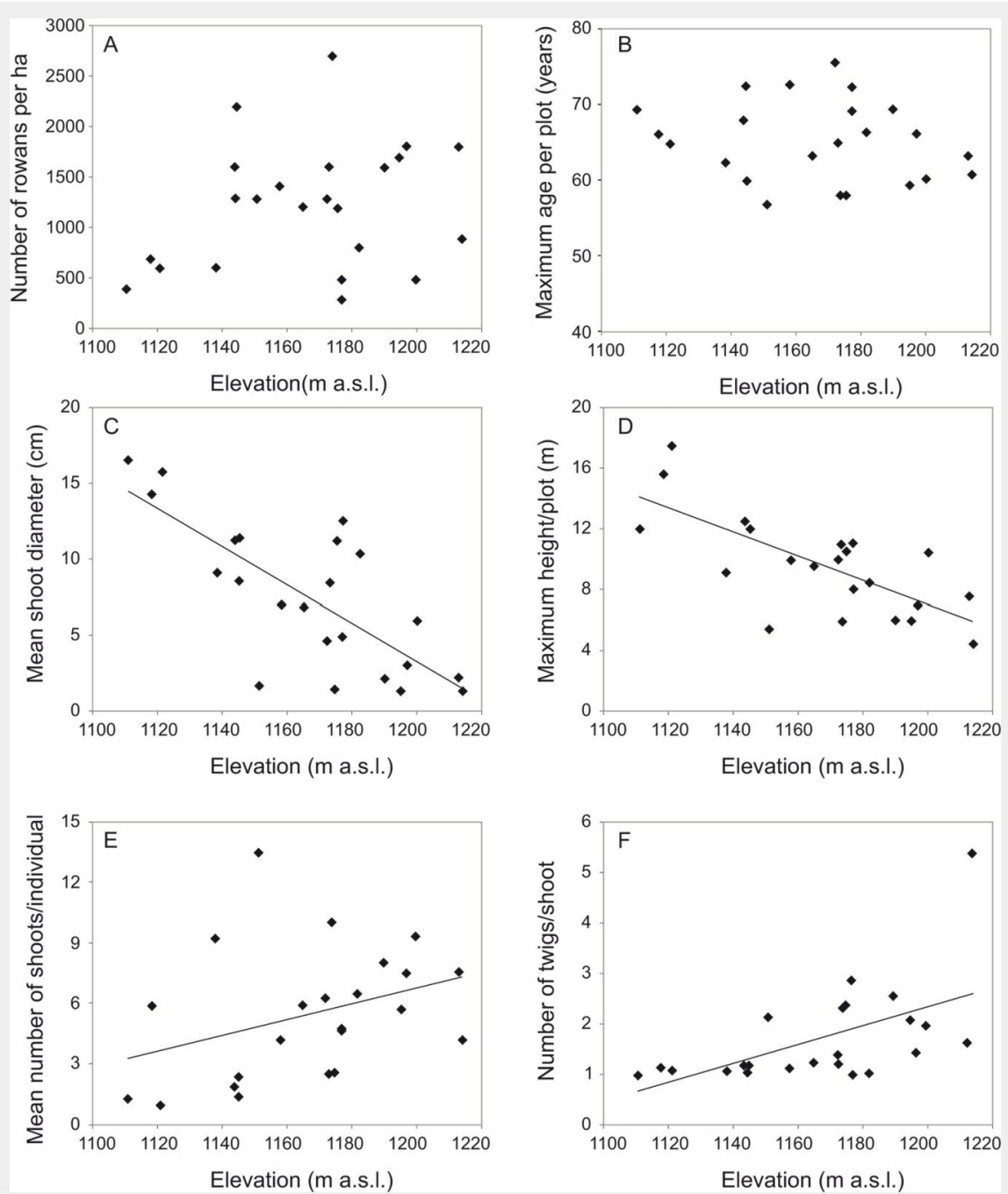

Fig. 4 - Relationship between elevation and: (A) rowan tree density; (B) age of oldest rowans in the plot; (C) mean shoot diameter; (D) maximum height of rowan trees; (E) mean number of stems per rowan tree; and (F) mean number of twigs per stem at breast height. in growth form characteristics of rowan. Elevation was the most influential factor, that negatively affected mean shoot diameter and the associated maximum height, and positively affected the mean number of twigs per shoot at breast height and mean number of shoots per individual (Tab. 1, Fig. 4). As regards other explanatory variables, slope had a positive effect on mean total basal area, while the effect of aspect and soil type was not significant.

\section{Discussion}

Rowan was the main woody species encroaching on the studied meadows along the whole elevational gradient. Moreover, rowan dominated on both the $\mathrm{NE}$ and SW slopes of the massif, from the beech forest limit to the mountain ridge. Similar situations have been reported in other abandoned subalpine meadows on Western Bieszczady Mountains (Winnicki 1999, Durak \& Zywiec 2013, Durak et al. 2015). This kind of forest community is quite uncommon in the scientific literature. In the subalpine zone of the Massif Central in France, Schaminée et al. (1992) described scrub communities dominated by Sorbus species on abandoned pastures, with $S$. aucuparia being the most common species. Borysiak (1985) found both shrublands and woodlands formed by rowans at the natural upper forest limit on the Babia Góra Massif (western Carpathians, Poland). Kullman (1986) reported a high frequency of rowan trees in the subalpine zone of the Scandes in Sweden. Subalpine communities with only a small admixture of rowan in the woody species composition were reported more frequently (Motta 2003, Šibík et al. 2005, Zywiec et al. 2013).

Before their abandonment, subalpine meadows in the study area bordered the forest dominated by F. sylvatica, with small admixtures of $A$. pseudoplatanus, P. abies, A. alba and S. aucuparia (Schramm 1958, Zarzycki 1963). Soon after abandonment, scrubland dominated by $A$. viridis grew above the forest limit, with S. aucuparia, A. pseudoplatanus, S. silesiaca and Rosa pendulina being less frequent (Schramm 1958, Zarzycki 1963). All these species still occur in the vegetation on the abandoned meadows, though rowan became dominant since 1990 (Winnicki 1999) and now is largely the most abundant species, in particular in terms of basal area. The role of rowan in the stand increased significantly with elevation, which suggests that this species is more able to colonize subalpine meadows than any other woody species present in the area. This is surprising because rowan was rare in the studied meadows in the 1950 s and 1960 s, and because its mode of dispersal by animals (mainly birds) does not facilitate the fast colonization of large open areas. Hill et al. (1992) showed rowan invading abandoned hill pastures at sites located in the close vicinity of bird perches. However, it is possible that birds were not the main seed dispersers in the studied 
area. Rowan seeds could have been supplied as a result of past pasture management practices and the former presence of livestock. In this case, rowan regeneration may have started in the meadow area long before its abandonment. Ungulates can be effective seed dispersers (Jaroszewicz 2013), facilitating seedling emergence by trampling and exposing the bare soil, by reducing competition with grasses, and by promoting upslope migration as seed dispersers. Unlike mowing, grazing may facilitate seedling establishment in grassland (Cairns \& Moen 2004, Julien et al. 2006). In an experimental study it was found that intense grazing by sheep increased rowan seedling recruitment (Hester et al. 1996). Rowan can survive for decades under suppression and grazing pressure, due to its ability to replace dead stems with new ones (Zywiec \& Holeksa 2012). This ability gives it an advantage over the other woody species in the area, and could have supported the presence of a rowan population in subalpine meadows before abandonment.

In the studied subalpine meadow, rowan expanded at approximately the same time along the entire elevational range, covering areas from the sheltered vicinity of the beech forest limit to exposed fragments on the mountain ridge. The recorded age of the oldest rowans differed only slightly between plots, and their mean age matched the time since the abandonment of meadows. These findings might be explained in two ways. The first hypothesis is that the seeds were dispersed and seedlings were established throughout the whole area at the same time. This assumes that the probability of seed supply and seedling establishment was high and equal throughout the whole area. This seems unlikely, as rowan is considered a slow colonizer of open areas (Zywiec \& Ledwon 2008). Moreover, the dispersal by animals usually results in a very uneven distribution of seeds and seedlings (Schupp 1993, Clark et al. 1998). The second explanation is that seedling development in the meadow vegetation was inhibited by adverse biotic or abiotic conditions. Most likely the inhibiting factor was pastoralism. Rowan seedlings lasted under grazing pressure in pasture vegetation for a long period of time, and their vertical growth accelerated when such pressure ceased. Under this second scenario the age of individuals should differ, but this difference could not be detected in this study as we took core samples at $30 \mathrm{~cm}$ above the ground, i.e., a height threshold not reached by woody plants growing in pastures. In the case of long-term persistence under grazing pressure, the growth increments at ground level would hardly ever show the real age of individuals. As rowan could survive under grazing pressure, it was likely that suppressed individuals accumulated over time (Zywiec \& Holeksa 2012). Previous works have shown that young rowans can markedly increase their growth rate after suppression ceases (Hester et al. 1996, Zywiec 2008). All these features of the regeneration strategy of rowan make the second explanation much more probable. Whatever the case of seedling establishment, rowan tree stands expanded in the studied area almost simultaneously, as evidenced by the narrow range of ages of the measured trees.

In this study, density of rowan trees did not decrease with increasing elevation and distance to the forest limit and decreasing distance to the mountain ridge. This result suggests that environmental conditions are suitable for regeneration and growth along the whole elevational gradient, confirming the broad edaphic and climatic amplitude of rowan. This species is adapted to a short growing season in that it stops shoot growth early, allowing buds to harden before freezing (Barclay \& Crawford 1982, Raspé et al. 2000) and tolerates an extremely low stem water potential corresponding to the minimum values in sclerophyllous plants (Vogt \& Lösch 1999). Furthermore, rowan bears mechanical damage very well, forming the wound periderm rapidly (Woodward \& Pocock 1996), and it has a high vegetative regeneration capacity (Kullman 1986). Indeed, plants are often multi-stemmed and the sprouting mechanism can very effectively extend their lifespan (Zywiec \& Holeksa 2012). All these features facilitated rowan survival in the harsh conditions of the mountain ridge.

The rowans' growth form changed along with elevation. At higher elevations rowans were shorter, their stems were thinner, and they had more shoots per plant than at lower elevations; in other words, they were more compact and more shrub-like. This trend is well known in mountain woody species (Bolli et al. 2007, Holtmeier 2009). Short-stature plants are less affected by temperature and snow cover better protects low-growing plants from freezing (Holtmeier 2009). A multi-stemmed form and the ability to sprout are important features enabling the rowan to survive the harsh mountain conditions, especially close to ridges. Vegetative reproduction by stump sprouts gives an advantage under stem breakage by wind, avalanches or heavy snow loads (Bellingham \& Sparrow 2000, Holtmeier 2009). Rowan shows high sprouting ability (Kullman 1986, Zywiec \& Holeksa 2012), and multi-stemmed individuals can survive for decades or longer through shoot turnover.

An interesting question is whether the rowan tree stands will be a long-lasting forest formation in this area, or rowan is rather only a pioneer species which will be displaced by other woody species in the long run. In other Carpathian ranges, rowan trees are usually overtopped and replaced by spruce, and it is reported that young spruces take advantage of improved soil conditions resulting from deposition of rowan litter (Emmer et al. 1998). At pre- sent, no tree species can be considered a quick successor of rowan in the subalpine area of the Bieszczady mountains. It is most probable that beech stands will expand and replace rowans, though this will take a very long time due to constrains on dispersal of beech nuts. In fact, we recorded this species only in the lowermost plots. However, beech forest is thought to have covered the mountain ridges up to $1250 \mathrm{~m}$ a.s.l. until the $15^{\text {th }}$ century (Kubijowicz 1926, Palczynski 1962). Another candidate for replacing rowan is sycamore, which was recorded on every second plot with similar frequency along the whole elevational gradient but with much lower abundance. Its seeds are dispersed by wind and can easily reach anywhere in subalpine areas. However, A. pseudoplatanus is less shade tolerant than F. sylvatica (Niinemets \& Valladares 2006). It has been found that more shade tolerant species can maintain foliage in deeper shade, support larger leaf area indexes and harvest more light (Niinemets 2010). It might be hypothesized that coexistence would be more probable if light demanding rowan grows together with moderate shade tolerant sycamore than with very shade tolerant beech. Such mixed rowan-sycamore stands are well known in the Polish Carpathians (Michalik \& Szary 1997, Matuszkiewicz 2001). Therefore, we hypothesize that rowan or mixed rowan-sycamore stands will be most likely the main element of the subalpine belt in this region in the upcoming decades.

\section{Acknowledgements}

We thank the authorities and staff of Bieszczady National Park for their kind cooperation and for granting permission to conduct research in the Park. This study was supported by the National Science Center (grant no. N N305 390739). The statutory funds of the University of Rzeszów and the W. Szafer Institute of Botany of the Polish Academy of Sciences also provided partial funding.

\section{References}

Albert CH, Thuiller W, Lavorel S, Davies ID, Garbolino $\mathrm{E}$ (2008). Land-use change and subalpine tree dynamics: colonization of Larix decidua in French subalpine grasslands. Journal of Applied Ecology 45: 659-669. - doi: 10.1111/j.13652664.2007.01416.x/pdf

Barclay AM, Crawford RM (1982). Winter desiccation stress and resting bud viability in relation to high altitude survival in Sorbus aucuparia L. Flora 172: 21-34.

Bellingham PJ, Sparrow AD (2000). Resprouting as a life history strategy in woody plant communities. Oikos 89: 409-416. - doi: 10.1034/j.16 00-0706.2000.890224.x

Bolli JC, Rigling A, Bugmann H (2007). The influence of changes in climate and land-use on regeneration dynamics of norway spruce at the treeline in the Swiss Alps. Silva Fennica 41: 5570. - doi: 10.14214/sf.307

Borysiak J (1985). Zespól jarzebiny Athyrio-Sor- 
betum Ass. nova w strefie górnej granicy lasu masywu Babiej Góry (Beskid Zachodni) [Athyrio-Sorbetum ass. nova in the zone of upper forest limit in the Babia Góra massif (Western Beskidy Mountains)]. Badania Fizjograficzne nad Polska Zachodnia Seria B 36: 116-133. [in Polish]

Bryn A (2008). Recent forest limit changes in south-east Norway: effects of climate change or regrowth after abandoned utilisation? Norsk Geografisk Tidsskrift, Norwegian Journal of Geography 62: 251-270. - doi: 10.1080/0029195 0802517551

Cairns DM, Moen J (2004). Herbivory influences tree lines. Journal of Ecology 92: 1019-1024. doi: 10.1111/j.1365-2745.2004.00945.x

Camarero JJ, Gutiérrez E (2004). Pace and pattern of recent treeline dynamics: response of ecotones to climatic variability in the Spanish Pyrenees. Climatic Change 63 (1-2): 181-200. doi: 10.1023/B:CLIM.0000018507.71343.46 Chauchard S, Beilhe F, Denis N, Carcaillet C (2010). An increase in the upper tree-limit of silver fir (Abies alba Mill.) in the Alps since the mid-2 $0^{\text {th }}$ century: a land-use change phenomenon. Forest Ecology and Management 259: 1406-1415. - doi: 10.1016/j.foreco.2010.01.009

Clark JS, Macklin E, Wood L (1998). Stages and spatial scales of recruitment limitation in southern Appalachian forests. Ecological Monographs 68 (2): 213-235. - doi: 10.1890/00129615(1998)068[0213:SASSOR]2.0.CO;2

Didier L (2001). Invasion patterns of European larch and Swiss stone pine in subalpine pastures in the French Alps. Forest Ecology and Management 145: 67-77. - doi: 10.1016/S03781127(00)00575-2

Durak T, Zywiec M (2013). Woody vegetation in abandoned subalpine meadows of the Western Bieszczady Mts. Acta Biologica Cracoviensia Series Botanica 55 (Suppl. 1): 43.

Durak T, Zywiec M, Ortyl B (2013). Rozprzestrzenianie sie drzewiastych zarosli w pietrze polonin Bieszczad Zachodnich [Expansion of brushwood in the subalpine zone of the Western Bieszczady Mts.]. Sylwan 157: 130-138. [in Polish]

Durak T, Zywiec M, Kapusta P, Holeksa J (2015). Impact of land use and climate changes on expansion of woody species on subalpine meadows in the Eastern Carpathians. Forest Ecology and Management 339: 127-135. - doi: 10.1016/ j.foreco.2014.12.014

Emmer IM, Fanta J, Kobus AT, Kooijman A, Sevink J (1998). Reversing borealization as a means to restore biodiversity in Central-European mountain forests - an example from the Krkono'se Mountains, Czech Republic. Biodiversity and Conservation 7: 229-247. - doi: 10.1023/A:1008840603549

Gehrig-Fasel J, Guisan A, Zimmermann NE (2007). Tree line shifts in the Swiss Alps: climate change or land abandonment? Journal of Vegetation Science 18: 571-582. - doi: 10.1111/j.16 54-1103.2007.tb02571.x

Hester AJ, Mitchell FJG, Kirby KJ (1996). Effects of season and intensity of sheep grazing on tree regeneration in a British upland woodland. Forest Ecology and Management 88: 99-106. doi: 10.1016/S0378-1127(96)03815-7

Hill MO, Evans DF, Bell SA (1992). Long-term effects of excluding sheep from hill pastures in north Wales. Journal of Ecology 80: 1-13. - doi: $10.2307 / 2261058$

Hofgaard A (1993). Structure and regeneration patterns in a virgin Picea abies forest in northern Sweden. Journal of Vegetation Science 4: 601-608. - doi: 10.2307/3236125

Holeksa J, Zywiec M (2005). Spatial pattern of a pioneer tree seedling bank in old-growth European subalpine spruce forest. Ekológia 24: 263276.

Holtmeier F-K, Broll G (2007). Treeline advance driving processes and adverse factors. Landscape Online 1: 1-33. - doi: 10.3097/LO.200701

Holtmeier F-K (2009). Mountain timberlines ecology, patchiness, and dynamics. Advances in Global Change Research 36, Springer Science + Business Media BV, The Netherlands, pp. 438. [online] URL: http://books.google.com/books? id=-C8y6VboJO8C

Jaroszewicz B (2013). Endozoochory by European bison influences the build-up of the soil seed bank in subcontinental coniferous forest. European Journal of Forest Research 132: 445452. - doi: 10.1007/s10342-013-0683-4

Jonášova $M$, Prach K (2004). Central-European mountain spruce (Picea abies (L.) Karst.) forests: regeneration of tree species after a bark beetle outbreak. Ecological Engineering 23: 1527. - doi: 10.1016/j.ecoleng.2004.06.010

Julien M-P, Alard D, Balent G (2006). Patterns of ash (Fraxinus excelsior L.) colonization in mountain grasslands: the importance of management practices. Plant Ecology 183: 177-189. doi: 10.1007/s11258-005-9019-x

Kozak J (2003). Forest cover changes in the Western Carpathians over the past 180 years: a case study from the Orawa region in Poland. Mountain Research and Development 23: 369375. - doi: 10.1659/0276-4741(2003)023[0369:FC CITW]2.0.CO;2

Kubijowicz W (1926). Zycie pasterskie w Beskidach Wschodnich [Pastoral life in the Eastern Beskidy Mountains]. Prace Instytutu Geograficznego UJ 5, Kraków, Poland, pp. 138. [in Polish]

Kucharzyk S, Augustyn M (2008). The upper forest limit dynamics in the Western Bieszczady Mts. - changes over a century and a half. Studia Naturae 54 (2): 33-156.

Kucharzyk S, Augustyn M (2012). The upper forest limit within the villages of Ustrzyki Górne and Wolosate (Bieszczady Mts.) in the end of eighteenth century. Roczniki Bieszczadzkie 20: 15-27.

Kucharzyk S (2004). Zmiany przebiegu górnej granicy lasu w pasmie Szerokiego Wierchu w Bieszczadzkim Parku Narodowym [Changes of upper forest limit in the Szeroki Wierch range (Bieszczady National Park)]. Roczniki Bieszczadzkie 12: 81-102. [in Polish]

Kullman L (1986). Temporal and spatial aspects of subalpine populations of Sorbus aucuparia in Sweden. Annales Botanici Fennici 23: 267-275. [online] URL: http://www.jstor.org/stable/2372 6195

Matuszkiewicz JM (2001). Zespoly lesne Polski [Forest associations of Poland]. PWN, Warszawa, Poland, pp. 357. [in Polish]

Michalik S, Szary A (1997). Zbiorowiska lesne Bieszczadzkiego Parku Narodowego [Forest plant communities of the Bieszczady National Park]. Monografie Bieszczadzkie 1: 1-175. [in Polish]

Mirek Z, Pienkos-Mirek H, Zajac A, Zajac M (2002). Flowering plants and pteridophytes of Poland. A checklist. W. Szafer Institute of Botany, Polish Academy of Sciences, Kraków, Poland, pp. 441.

Motta R (2003). Ungulate impact on rowan (Sorbus aucuparia L.) and Norway spruce (Picea abies (L. ) Karst. ) height structure in mountain forests in the eastern Italian Alps. Forest Ecology and Management 181: 139-150. - doi: 10.1016/ S0378-1127(03)00128-2

Niinemets $U$ (2010). A review of light interception in plant stands from leaf to canopy in different plant functional types and in species with varying shade tolerance. Ecological Research 25: 693-714. - doi: 10.1007/s11284-010$0712-4$

Niinemets $U$, Valladares $F$ (2006). Tolerance to shade, drought, and waterlogging of temperate northern hemisphere trees and shrubs. Ecological Monographs 74: 521-547. - doi: 10.1890/ 0012-9615(2006)076[0521:TTSDAW]2.0.CO;2

Okland RH, Okland T, Rydgren K (2001). Vegetation-environment relationships of boreal spruce swamp forests in Ostmarka Nature Reserve, SE Norway. Sommerfeltia 29: 1-190.

Palczynski A (1962). Laki i pastwiska w Bieszczadach Zachodnich [Meadows and pastures in the West Bieszczady mountains]. Studia geobotaniczno-gospodarcze, Roczniki Nauk Rolniczych, Ser. D - Monografie 99-D, PWRiL, Warszawa, Poland, pp. 128. [in Polish]

Raspé O, Findlay C, Jacquemart A-L (2000). Sorbus aucuparia L. Journal of Ecology 88: 910-930. - doi: 10.1046/j.1365-2745.2000.00502.x

Regent Instruments (2012). WinDendro for treering analysis. Regent Instruments Canada Inc., Web site. [online] URL: http://www.regentin struments.com/assets/windendro_about.html Schaminée JHJ, Jansen J, Hennekens SM (1992). Scrub communities dominated by Sorbus species in the subalpine zone of the Monts du Fez (Massif Central, France). Proceedings of the Konginklijke Nederlandse Akademie van Wetenschappen. Biological, Chemical, Geological, Physical and Medical Sciences 95: 473-495. [online] URL: http://www.cabdirect.org/abstra cts/19930668895.html

Schramm W (1958). Lasy i zwierzyna Gór Sanockich [Forests and wild game of the Sanockie mountains]. PWN, Poznan, Poland, pp. 113. [in Polish]

Schupp E (1993). Quantity, quality and the effectiveness of seed dispersal by animals. Vegetatio 107/108: 15-29. - doi: 10.1007/978-94-011-17494_2

Sitko I, Troll M (2008). Timberline changes in relation to summer farming in the Western Chornohora (Ukrainian Carpathians). Mountain Research and Development 28: 263-271. - doi: 10.1659/mrd.0963

Skiba S, Drewnik M, Szmuc R (1998). Gleby Bieszczadzkiego Parku Narodowego [Soils of the Bieszczady National Park]. Monografie Bieszczadzkie 2, Bieszczadzki Park Narodowy, Ustrzyki Dolne, Poland, pp. 88. [in Polish]

Šibík J, Walachovič M, Kliment J (2005). Plant communities with Pinus mugo (alliance Pinion 
Mugo) in the subalpine belt of the Western Carpathians - a numerical approach. Acta Societatis Botanicorum Poloniae 74 (4): 329-343.

Tasser E, Walde J, Tappeiner U, Teutsch A, Noggler W (2007). Land-use changes and natural reforestation in the Eastern Central Alps. Agriculture, Ecosystems and Environment 118: 115129. - doi: 10.1016/j.agee.2006.05.004

Vogt UK, Lösch R (1999). Stem water potential and leaf conductance: a comparison of Sorbus aucuparia and Sambucus nigra. Physics and Chemistry of the Earth (B) 24 (1-2): 121-123. - doi: 10.1016/S1464-1909(98)00022-7

Weisberg PJ, Shandra O, Becker M (2013). Landscape influences on recent timberline shifts in the Carpathian Mountains: abiotic influences modulate effects of land-use change. Arctic, Antarctic and Alpine Research 45: 404-414. doi: 10.1657/1938-4246-45-3.404

Winnicki T (1999). Zbiorowiska roslinne polonin Bieszczadzkiego Parku Narodowego (Bieszczady Zachodnie, Karpaty Wschodnie) [Plant communities of subalpine meadows (poloni- nas) in the Bieszczady National Park (Western Bieszczady Mts, Eastern (arpathians)]. Monografie Bieszczadzkie 4, Bieszczadzki Park Narodowy, Ustrzyki Dolne, Poland, pp. 215. [in Polish]

Woodward S, Pocock S (1996). Formation of the ligno-suberized barrier zone and wound periderm in four species of European broad-leaved trees. European Journal of Forest Pathology 26: 97-105. - doi: 10.1111/j.1439-0329.1996.tboo7 14.x

Zarzycki K (1963). Lasy Bieszczadów Zachodnich [The forests of the Western Bieszczady Mts.]. Acta Agraria et Silvestria Seria Lesna 3: 3-132. [in Polish]

Zerbe S (2001). On the ecology of Sorbus aucuparia (Rosaceae) with special regard to germination, establishment and growth. Polish Botanical Journal 46 (2): 229-239.

Zywiec M (2008). The growth rate of rowan (Sorbus aucuparia L.) versus subalpine spruce stand breakdown. Sylwan 4: 38-45.

Zywiec M, Holeksa J (2012). Sprouting extends the lifespan of tree species in a seedling bank: 12-year study. Forest Ecology and Management 284: 205-212. - doi: 10.1016/j.foreco.2012.08.007 Zywiec M, Holeksa J, Wesolowska M, Szewczyk J, Zwijacz-Kozica T, Kapusta P (2013). Sorbus aucuparia regeneration in a coarse-grained spruce forest - a landscape perspective. Journal of Vegetation Science 24: 735-743. - doi: 10.1016/j.foreco.2012.08.007

Zywiec M, Ledwon M (2008). Spatial and temporal patterns of rowan (Sorbus aucuparia L.) regeneration in subalpine spruce forest in West Carpathians. Plant Ecology 194: 283-291. - doi: 10.1007/s11258-007-9291-z

\section{Supplementary Material}

Appendix 1 - Pearson's correlation coefficients for tree stand and rowan growth form data.

Link: Durak_1470@supplo01.pdf 